\title{
US-Hungarian Relations Ten Years After 1956
}

\author{
Tibor Glant
}

\begin{abstract}
Revolution, was a key year in USHungarian relations. Diplomatic relations were raised from the lowest to the highest level, but suspicion and tension remained. Neither side knew what to expect from the other on account of the anniversary, the Vietnam War, economic and cultural negotiations, and the fate of Cardinal Mindszenty. A traditional diplomatic historical approach is supplemented here with cultural materials to present the full scale of contacts ranging from high political issues to the visit of Hollywood movie star Kirk Douglas in Budapest. First Secretary of the Legation for Press and Cultural Affairs Edward Alexander receives special attention, because he played a crucial role in the events of 1966. As press secretary, he helped calm Hungarian fears over what American journalists might report about the anniversary, while as cultural affairs officer he worked on documenting and expanding American cultural presence in Hungary. In the latter capacity, he opened the USIA Library at the Legation, fraternized with blacklisted painters of the Zuglói Kör ['Zugló Circle'], monitored the Hungarian stage production of My Fair Lady, and reported on the publication of American literature in Hungarian.
\end{abstract}

Keywords: United States-Hungarian relations, Cold War, 1956 Revolution and War of Independence, Vietnam War, My Fair Lady, Kirk Douglas, Edward Alexander, János Kádár, Hungarian art, USIA, cultural diplomacy

Biography: Tibor Glant majored in History and English at the University of Debrecen (1986-91) and earned an MA (1992) and a PhD (1996) in History from the University of Warwick, UK. He has taught various courses on American history and culture (including US-Hungarian relations) since 1991 at various universities in the UK, Germany, the Netherlands, Rumania, the United States, and Hungary. He has served as chair of the North American Department in Debrecen since 2002 and as director of the American Studies doctoral program since 2011. He is the current president of the Hungarian Association of American Studies and director of the Center for International Migration Studies at Debrecen. He published six scholarly books (two in English) and numerous articles on various aspects of twentieth-century US-Hungarian relations. This article is a byproduct of his recently completed second Fulbright (with Texas Christian University, Fort Worth, TX). Website: http://ieas.unideb.hu/glant

1966 marked the tenth anniversary of the 1956 Hungarian Revolution and War of Independence as well as the end of arguably the most hostile decade in American-Hungarian relations and the first steps towards "normalization." In this paper first we will review the major events of the year in bilateral relations and then introduce a hitherto neglected dimension: the role of American cultural diplomacy through the reports of First Secretary of the Legation for Press and Cultural Affairs Edward Alexander. In the ten years between 1956 and 1966, the 
Glant, Tibor. "US-Hungarian Relations Ten Years After 1956.” Hungarian Cultural Studies. e-Journal of the American Hungarian Educators Association, Volume 9 (2016): http://ahea.pitt.edu DOI: 10.5195/ahea.2016.262

United States reduced diplomatic presence to the lowest possible level and was represented by temporary Charges d'Affaires in communist Hungary. Then, in November 1966 the two countries agreed to raise permanent diplomatic representation to the highest level and struck an agreement about exchanging ambassadors for the first time ever (Kovrig 1991: 103-9). To understand this dramatic shift in relations we must take a cursory look at the history of those ten troubled years.

After the suppression of the 1956 Revolution communist dictator János Kádár was more interested in stabilizing his domestic control and political standing within the Soviet Bloc than in getting his country out of the ensuing diplomatic isolation from the West. A brutal campaign of retaliation was combined with a typical totalitarian war on memory: "the unfortunate events of October" were dubbed as a "counter-revolution" sponsored by "Western imperialists" (especially the CIA), "Horthy-fascists" (residing in West Germany), and "criminal elements" inside the country. By the mid-1960s a new, supplementary narrative emerged: there were "mistakes of the past" but the new regime had "realized many of the goals of 1956" in a peaceful manner. By 1960, however, it became obvious to the Party leadership in Budapest that Hungary needed to improve its relations with the West to boost the economic performance of the country and get loans in hard currency. This was a key element of the so-called "Kádár compromise" forced upon a Hungarian society not allowed to digest the 1956 trauma: people would accept the official communist narrative of the events in return for a standard of living higher than in any of the neighboring communist regimes. The 1960 partial amnesty was the first symbolic, and impactful, step that signaled a new course in Budapest. It was followed by an economic opening towards West Germany and attempts to feel out Washington's willingness to resume the discussion of outstanding bilateral issues. The Kennedy White House made it clear that any improvement in bilateral relations hinged on a general amnesty for revolutionaries still in jail (Borhi 2015: 173-217).

For the Eisenhower administration in the United States, October-November 1956 was an eventful period: the twin upheavals in Poland and Hungary coincided with the end of the presidential election campaign while the Middle East was rocked by the Suez crisis. The two superpowers carefully avoided direct interference in the other's sphere of influence during the course of the events (the United States in Eastern Europe and the Soviet Union in Egypt), but both pushed for United Nations action post facto (McCauley 1981). To avoid a Soviet veto, the US brought the "Hungarian problem" (or the "Hungarian question") before the General Assembly and not the Security Council. The Soviet Union was condemned for violating Hungarian sovereignty and the Kádár regime for the political executions and other massive violations of human rights. A "Special Committee" (also known as the "Committee of Five") was set up to investigate the events before, during, and after the Revolution. Its final report was submitted in the summer of 1958, just as Imre Nagy and other revolutionary leaders were being executed in Hungary. Also in 1958 Sir Leslie Munro of New Zealand was appointed UN Special Representative to monitor the situation in Hungary. His work was terminated in late 1962, as a result of a deal between Budapest and Washington (Luard 1989: 58-74).

Washington agreed to remove the "Hungarian question" from the UN agenda in return for the "general amnesty" demanded by the Kennedy administration, which took place in 1963. The next year, Budapest negotiated a diplomatic accord with the Vatican without involving the United States, although Cardinal József Mindszenty was still enjoying the hospitality of the US 
Legation in Budapest, where he had sought refuge on November 4, 1956. Additional unresolved problems between the US and Hungary further complicated bilateral relations, including financial claims on both sides, disagreements over the future course of cultural relations, the fate of the Hungarian Holy Crown and assorted coronation regalia, politically active Hungarian immigrants in the US opposing any attempt at rapprochement, and public Hungarian government-level hate speech targeting the United States on account of the Vietnam War. That notwithstanding, less than two years after the "hottest moment of the Cold War" (the Cuban Missile Crisis of October-November 1962), President Lyndon Johnson announced a new policy of "bridge building" towards the Soviet Bloc (Borhi 2015: 221-30).

Still, what ensued was an ugly tug of war between Budapest and Washington, with fist shaking and finger pointing. Hungary negotiated not to settle outstanding bilateral issues but to publicly peg the United States as an imperialist power trying to interfere in the domestic affairs of other countries. In this new Hungarian strategy cultural diplomacy was linked to the Vietnam War in a unique way: alone in the Soviet Bloc, Budapest refused to sign a bilateral cultural exchange agreement before American withdrawal from Vietnam. The reason for this was that while anything American was welcomed by the general Hungarian public, a paranoid Party leadership viewed all American attempts at cultural diplomacy, including art, academic exchanges, and the Peace Corps, as subversive action (Borhi 2015: 231-42). And these communist fears were not unfounded: between the 1880s and 1945, Hungarians systematically studied the culture, political system, and economy of the United States and developed an overtly positive image of the transatlantic "Promised Land." American popular culture (especially film and pulp fiction) had played a crucial role in shaping Hungarian culture between the world wars, and postwar communist hate speech about the "exploitation of the working class" and "fascist American geopolitics" carried little credibility with the general public (Szemjonov 1953, Glant 2008, 2010, 2013). At the same time, the State Department successfully wielded the appeal of American culture as a "weapon" in the Cold War through the United States Information Agency (USIA) and private partners like the Ford Foundation as well as universities, such as Columbia, Harvard, and the University of California. In this world of politically driven cultural diplomacy Americans preferred exchanges in the fields of performing and fine arts, as well as history, political science, and sociology, while Hungary wanted to send natural scientists and agricultural experts to circumvent trade and technology transfer restrictions. In other words, the communist government of Hungary hoped to access American agricultural technology, farm products, and items on the COCOM list (Medails 2009: 134-59).

The first post-1956 round of bilateral negotiations began in 1964. Hungary made multiple concessions, including signing an agreement with the Ford Foundation for international exchanges, agreeing to stop jamming Radio Free Europe and Voice of America broadcasts, and inviting American businesses to participate at the annual Budapest International Fair in 1965. At the same time, orthodox communists (mostly in the Ministry of the Interior) felt that American cultural penetration had gone too far, and took action. On February 13, 1965 a regular, "spontaneous" demonstration against the Vietnam War was held outside the US Legation in Szabadság tér ['Freedom Square'], in the heart of Budapest. This time, however, demonstrators broke into the American mission and ravaged the building. The US suspended bilateral talks, and Budapest decided to go along, citing American human rights violations in Vietnam as the main reason (Borhi 2015: 231-9). October 1966, the tenth anniversary of the Revolution, rolled 
around in an atmosphere of thinly veiled hostility and suspicion. Meanwhile, in August 1965 Edward Alexander arrived in Budapest. He was to play a key part in shaping and reporting on the events of 1966.

Available diplomatic records indicate limited activity on both sides in 1966. A new round of negotiations was initiated by the Americans in April, which the Hungarians accepted. The Hungarian Foreign Ministry wanted to focus on the financial claims settlement and trade relations while cutting back on cultural advances. The State Department was interested in moving forward on the Mindszenty issue and wanted to expand cultural ties. Negotiations came to a halt again, until a tragic event in the fall set things in motion once more. On September 23 Charge d'Affaires ad interim Elim O'Shaughnessy passed away unexpectedly. On October 8, Hungarian Foreign Minister János Péter and US Secretary of State Dean Rusk met in person. Péter again raised the issue of exchanging ministers, and Rusk agreed when he was told that Budapest did not consider Cardinal Mindszenty's presence at the Legation an obstacle. On November 11, Hungarian Charge d'Affaires János Radványi was officially informed by the State Department that the United States was ready to elevate bilateral relations and exchange ambassadors (Borhi 2015: 241-2).

The fact that a decade-long standoff was cleared up within three weeks of the tenth anniversary of the outbreak of the revolution suggests that what did not happen mattered just as much as what did happen. Demonstrations against the Vietnam War continued outside the US Legation in Budapest, but the building itself was not attacked in 1966. At the same time, US media coverage of the anniversary tended to focus as much on the present as on the past. A case in point is Ken Foote's seven-page special article for the Sunday magazine section of the New York Times on November 20 (Glant 2007: 8-9). In April, an NBC crew came to Budapest to shoot material for a documentary that would be shown on American television on November 13, under the title "Hungary-Ten Years After." The Hungarian Ministry of Foreign Affairs granted unprecedented access to people and locations to the six Americans, who, according to a report by Alexander, "never went beyond the limits defined by the MFA or the Legation, and checked out all sensitive themes with the Legation before proceeding." ${ }^{1}$ Traditional diplomatic historical records thus suggest that both parties wanted to err on the side of caution to avoid open confrontation over the events of ten years before. Still, if we dig deeper into cultural diplomatic records, i.e. Alexander's reports to the State Department on the scope and details of his daily work, a somewhat different story unfolds. In the second half of this paper we take a closer look at the performance of this most interesting American diplomat in Budapest during the crucial year of 1966.

Born in 1920 into an Armenian-American family, Alexander attended Columbia University and got a masters degree from its Graduate School of Journalism. During the Second World War he served in the Psychological Warfare Division of the US Army in Europe and in 1950 joined the Voice of America. He set up and operated the Transcaucasian Branch of VOA

\footnotetext{
1 "NBC Team Completes Filming Documentary on Hungary,” Budapest Legation to State, May 5, 1966, 2 pages, National Archives and Records Administration at College Park, MD, RG 59 General Records of the Department of State, Central Foreign Policy Files, 1964-66, Box 340, Folder: CUL 6 HUNG 1/1/64.
} 
and launched its Armenian program. From 1959 to 1964 he worked for RIAS (Radio in the American Sector) in West Berlin. In 1964 he was assigned to the Budapest legation, learned Hungarian in one year, and held his post until 1969. He later served in Athens and East Berlin, and was harassed by a KGB agent who tried, unsuccessfully, to turn him using his Armenian background as leverage against him. Alexander gave an in-depth interview on his professional career in 1988 and also penned a political memoir (Alexander 1990) as well as a fictitious intelligence thriller, Opus (2000), which takes place in Cold War Hungary (Tuch 1988). He is still alive at 96 and lives in retirement in Bethesda, Maryland.

As First secretary of the Legation for Press and Cultural Affairs, Alexander was tasked with both managing American press relations in Hungary and managing cultural diplomacy, two separate full-time jobs. In the first capacity, he had to mediate between American journalists and the communist government of Hungary. His four surviving reports on the press from 1966 indicate a relationship more complex than the one suggested by traditional diplomatic and press histories, including the present author's previous work (Glant 2007 and Borhi 2015). Alexander encountered a Hungarian government torn between the desire to move along the path of internal liberalization and insecurity over what American journalists might report about the tenth anniversary of the revolution. As press officer he ran into considerable red tape and had to work hard to ease such Hungarian fears and insecurities. As cultural affairs officer, however, he had to extend American cultural presence in Hungary even at the expense of feeding the same fears and insecurities. This duality makes his tour of duty in Hungary uniquely interesting.

Western journalists submitted the first requests to the Hungarian Foreign Ministry for anniversary coverage access as early as February 1966. Not only were these turned down, but an unnamed ministry official straightforwardly told a West German TV reporter, "This is not something we are going to celebrate." To prevent Hungarian students from being exposed to unwanted ideas, the Ministry of the Interior instructed all universities to restrict travel abroad programs for the fall. ${ }^{2}$ Thus, the visit of the NBC crew was more the exception than the rule, and its April visit emerged as the feel-good story of the year in press relations. Led by producer Gerald Green and journalist Frank Bourgholtzer, the American team interviewed high-ranking communist officials, prominent intellectuals, and people in the street. Only three of their requests were turned down: they were not granted a one-on-one with either Kádár or Mindszenty, and were denied access to the building of the Communist Party headquarters. In turn, as has been noted, they fully cooperated with the Hungarian Foreign Ministry and the US Legation. Hungarian insecurity was on full display when, during the shooting, Kitty Havas of the Foreign Ministry repeatedly asked Alexander to convince American journalists to not "dramatize" the anniversary "anymore than necessary." The American diplomat responded, "[E]very medium kept a morgue of background material for just such occasions, but... for the tenth anniversary of the Revolt, some would obtain new material which should allay the MFA's fears because if

2 "Hungarian Government Seeks to Minimize Anniversary of 1956 Revolt," Budapest Legation to State, February 23, 1966, 1 page, NARA, RG 59 General Records of the Department of State, Central Foreign Policy Files, 196466, Box 340, Folder: CUL 6 HUNG 1/1/64. 
Hungary had really achieved the aims of 1956, as is often heard in Budapest, all stories would reflect such progress." 3

The fall of 1966 brought both tension and relief for the Hungarian government. Tension grew with the coming of the anniversary (which, in turn, meant an increase in the number of press accreditation requests from the West) and insecurity over what might happen peaked when the head of the American diplomatic mission passed away in late September. The Péter-Rusk meeting in early October, however, yielded much needed relief: the American Secretary of State was not only willing to meet his Hungarian counterpart in person but also made a gesture by suggesting that instead of temporary representatives or ministers, ambassadors should be exchanged after O'Shaughnessy's death (Magyarics 1994: 140-4). Budapest interpreted this as a signal that Washington was not going to seek confrontation on October 23, so the Foreign Ministry felt less compelled to grant additional favors to the foreign press. The red tape went up again.

On November 3, Alexander reported five incidents involving American journalists, in which, however hard he tried, he could not help. Hughes Rudd of CBS Bonn, Stephen Nordlinger of the Baltimore Sun, Reuters correspondent William Kessler, and Washington Post journalist Anatloe Shub were all denied visas to enter Hungary for the weekend of October 23. The feel-good story of the spring also turned sour: NBC decided to delay the screening of the documentary shot in April in the hope that additional footage might be acquired from the actual anniversary in October. However, a request to be allowed to return was rejected on the excuse that he Foreign Ministry could accommodate only the six Western camera crews already in Budapest. Alexander pushed again, this time only for crew chief Bourgholtzer to come with but a hand-held camera; still, he was rebuffed: "NBC had already had its chance in April and had full cooperation from the MFA." On the other hand, the Shub story indicated that the Foreign Ministry was willing to take some risks even at such a potentially explosive moment. Instead of Shub, who was considered a friendly journalist by Budapest, Seymour Freidin of the WorldJournal-Tribune syndicate was admitted. His post-anniversary articles in the Paris Herald Tribune were described as downright "dirty" by a Hungarian official, who also noted the "Freidin did not have to come to Hungary to write them." Shub later told Alexander that since the Post owned half of the Herald Tribune, his articles would have enjoyed preference in the French edition of the paper over those of Freidin in terms of publication. The American diplomat gloatingly told the journalist that he should "make this point clear to the MFA.",

Edward Alexander the cultural diplomat arrived in Hungary with a clear purpose: he wanted to open the first USIA library in Budapest. As cultural affairs officer of the legation and

\footnotetext{
3 “GOH Concern over US Observance of 1956 Revolt," Budapest Legation to State, March 31, 1966, 2 pages and "NBC Team Completes Filming Documentary on Hungary,” Budapest Legation to State, May 5, 1966, 2 pages, NARA, RG 59 General Records of the Department of State, Central Foreign Policy Files, 1964-66, Box 340, Folder: CUL 6 HUNG 1/1/64. The quotes are from the second document.

4 “GOH Bars Journalists Covering Revolt Anniversary,” Budapest Legation to State, November 3, 1966, 3 pages, NARA, RG 59 General Records of the Department of State, Central Foreign Policy Files, 1964-66, Box 340, Folder: CUL 6 HUNG 1/1/64.
} 
given that British and French libraries were already operating in the Hungarian capital, he approached the Hungarian Ministry of Foreign Affairs with his plan. He was flatly turned down, but decided to go ahead nonetheless, although he was keenly aware that by opening the library in the building of the Legation (the only option left open by Hungarian authorities) he was risking still another "spontaneous" demonstration turning into a physical attack on the American mission. To take away the edge of this unilateral move, Alexander decided not to advertise the opening of the library and relied on word of mouth instead. On March 21, 1966 the opening ceremony took place with only seven Hungarians attending, and in the first three days altogether twelve reading visitors showed up. ${ }^{5}$ This was because the Ministry of the Interior monitored and intimidated people in touch with the American Legation and its diplomats (Borhi 2015: 235). Alexander upped the ante by starting to show films preapproved by the Foreign Ministry. By 1968, screenings at the (by then) Embassy had become the go to event in Budapest: in that year alone, more than a thousand people watched arguably the most highly-rated USIS documentary, John F. Kennedy: Years of Lightning, Day of Drums (1964). The American diplomat's "lasting achievement" left a mark on the intelligence services of the entire Soviet Bloc. Ten years later he was serving as the Public Affairs Officer of the US Embassy in East Berlin and proposed a similar library project. His communist counterpart rebuffed him: "We know you and we know what you did in Hungary. And I just want to tell you one thing. The German Democratic Republic is not Hungary" (Tuch 1988: 23-7).

The opening of the USIA library was an integral part of a broader project to extend and document American cultural influence in communist Hungary in the mid-1960s. Between October 1965 and December 1966, Alexander prepared detailed "Monthly Cultural Reports" for the State Department. At the end of 1966 he decided to terminate the project since the "preparation of the report was extremely time-consuming, demanding careful perusal of countless newspapers, magazines, books, film and theater schedules, radio listening, television watching and every kind of activity which contributed to the sum total of its monthly content." 6 His main interest was literature. In December 1965, Alexander wrote a summary report on the publication of American literary texts since the 1956 revolution and continued to list such pieces item by item in his monthly reports. He quickly grasped the significance of Nagyvilág ['Big World' in his translation], the leading literary monthly throughout the Kádár era, and cultivated its editors in person by providing them with both academic and literary materials. ${ }^{7} \mathrm{He}$ also

\footnotetext{
5 “Opening of Legation Library," Budapest legation to State, March 25, 1966, 2 pages, NARA, RG 59 General Records of the Department of State, Central Foreign Policy Files, 1964-66, Box 340, Folder: CUL 10-5 Hung $1 / 1 / 64$.

6 “Cessation of Monthly Cultural Report," Budapest Embassy to State, December 22, 1966, 1 page, NARA, RG 59 General Records of the Department of State, Central Foreign Policy Files, 1964-66, Box 340, Folder: CUL CULTURE HUNG 1/1/64. This folder has all the reports.

7 “American Fiction in Hungary Since 1945," Budapest Legation to State (Info: Moscow, Warsaw, Bucharest, Prague, Sofia, Berlin, and Vienna), December 31, 1965, 5 pages and "Literary Monthly Publishes American Authors," Budapest Legation to State, February 9, 1966, 4 pages, NARA, RG 59 General Records of the Department of State, Central Foreign Policy Files, 1964-66, Box 340, Folder: CUL 10-5 Hung 1/1/64.
} 
supervised the agreement between CBS and ARTISJUS (the Hungarian copyright agency) about the translation and stage production of My Fair Lady. ${ }^{8}$ The musical opened in February 1966, and Alexander was invited to a post-performance party in Fészek ['Nest,' the Hungarian Artists' Club] by translator Tamás Ungvári. The American diplomat reported that he had "the most substantive conversations" with his host on the difficulties of translation and the status of American culture in Hungary. ${ }^{9}$

Alexander's involvement with a group of blacklisted painters points to the subversive nature of his job as cultural diplomat. Communists tended to view art as a tool of achieving political goals. Therefore, abstract, nonfigurative painting was irreconcilable with the socialist concept of art and was promptly persecuted behind the Iron Curtain. When the American Library was opened, graphic artist Imre Bak came by and inquired about contemporary American abstract art. He informed the American diplomat that a group of painters was planning an exhibit, Új Törekvések ['New Strivings' in Alexander's translation], at the Ferihegy airport. But when they took a sample of their paintings to the Ministry of the Interior for approval, an official "took one look at the prospectus and was appalled. He was invited to see the paintings themselves, and when he did, he reportedly staggered out of the studio muttering about the insanity of modern art." The group in question was the Zuglói Kör ['Zugló Circle,' named after a suburb of Budapest where they regularly met], and the exhibit, of course, was banned (Andrási 1991). However, the Guggenheim Museum in New York City got word of the artists and asked for photographic images of their work. When Alexander saw the low quality of the prints in their homemade prospectus, he offered to take Kodachrome pictures and deliver them. He invited Bak and his fellow artists to his home to watch the USIA slide collection on contemporary American painting and requested additional materials through diplomatic channels. ${ }^{10}$ However, he was less impressed by the work of officially supported artists. In that hectic month of the anniversary of 1956, October 1966, Mücsarnok (one of the Budapest art galleries) hosted an exhibition of more than two hundred paintings by nine of the most recognized contemporary Hungarian artists working at home. Alexander visited the exhibit on the very last day to see both the paintings and the written feedback in the guest book. He reported a feeling of déjà vu: most of the paintings on display reminded him of "some painter of the French school from the early part of our century." Communist propaganda was all over the place, but "nowhere was there evidence of the many western schools of painting that have arisen since before World War II." He described contemporary nonfigurative artists as "cultural freedom fighters [who] are compelled to defend a position today which was not only defended but won by [their] western counterparts almost four

\footnotetext{
8 “My Fair Lady," Budapest Legation to State, November 2, 1965, 2 pages, NARA, RG 59 General Records of the Department of State, Central Foreign Policy Files, 1964-66, Box 340, Folder: CUL 10-5 Hung 1/1/64.

9 “Premier of 'My Fair Lady'," Budapest Legation to State, February 16, 1966, 3 pages, NARA, RG 59 General Records of the Department of State, Central Foreign Policy Files, 1964-66, Box 340, Folder: CUL 10-5 Hung $1 / 1 / 64$.

10 “Information Material for Young Artists' Group,” Budapest Legation to State, August 1, 1966, 2 pages, NARA, RG 59 General Records of the Department of State, Central Foreign Policy Files, 1964-66, Box 340, Folder: CUL 10-5 Hung 1/1/64.
} 
decades ago." 11 Alexander failed to realize that abstract art not conveying simplified, preapproved political messages was at best grudgingly tolerated in communist countries.

In April 1966 Hollywood film star Kirk Douglas visited Hungary and his stay produced one of the highlights of the year. He was a household name in Hungary, too, on account of Spartacus (1960), which he himself had produced and starred in. The Spartacus story was a classic class struggle epic that communists championed, but there was a lot more to this Kubrick classic. As producer, Douglas insisted that screenwriter Dalton Trumbo (one of the famous Hollywood Ten) be fully credited in the movie, thus breaking down the blacklist that had been in effect for much of the 1950s. Therefore, he was twice the hero when he came to Budapest during a tour of the Soviet Bloc (Ceplair and Trumbo 2015: chapters 18 and 19). His three demands in each country were to learn a local folk song, lecture a large student body, and meet the local Communist Party boss. Alexander described him as "a real difficult person. Edgy, prickly. But cooperative, too." Douglas' first request was easy to meet, the second one unlikely, the third one well-nigh impossible. And yet, in the end it was only Douglas' third request that ended up being met in Budapest. There was no official protocol for presenting an American movie star to a communist dictator, so this time Alexander had to improvise. He took Douglas to Mátyás Pince, since he knew that Kádár would have dinner there on occasion. He struck gold as the Hungarian communist dictator was indeed there that night with his wife. The American diplomat walked up to him, introduced himself in Hungarian, and asked the party boss if he wanted to meet Douglas. When they clarified that it was indeed the Kirk Douglas of Spartacus fame, Kádár agreed. The three-day visit also featured a lecture to some sixty guests from the world of Hungarian film and television, instead of a presentation in front of a large student body. Douglas was so happy with the meeting with Kádár that he chose not to learn a folk song. Alexander's ingenuity became a legend in American diplomatic circles since none of his fellow diplomats could arrange for a meeting between their local party bosses and the American actor (Tuch 1988: 20-3).

Hostility and suspicion provided the context for US-Hungarian relations throughout 1966. Diplomats of both countries needed special permits even to leave the capital city they were serving in, and both Legations were severely undermanned. After the February 1965 attack, the American mission lived under the gun as "spontaneous" demonstrations against the Vietnam War were a common sight on Szabadság tér. Official cultural relations also hit rock bottom when the United States banned Hungarian government officials from entering the country. This meant that even Alexander's most important contact, Gábor Vígh (the American Desk Officer in the Institute for Cultural Relations), could not go on a Ford Foundation scholarship "all because of Vietnam." Vígh confided to the American, "I might as well tell you, things are very bad, even for us. Please don't ask me to have lunch with you, either. Relations are worsening even to the

\footnotetext{
11 "Painting Exhibit Reveals Condition of Hungarian Art," Budapest Legation to State, November 14, 1966, 3 pages, NARA, RG 59 General Records of the Department of State, Central Foreign Policy Files, 1964-66, Box 340, Folder: CUL 10-5 Hung 1/1/64.
} 
degree that I must not be seen with you longer than is necessary."12 Always more willing to talk, Americans could not understand why Hungary was so uncompromising about Vietnam, while other Iron Curtain countries (with the exception of the Soviet Union and the GDR) were not. The key to this puzzle may be found not in Vietnam but in the Kádár regime's own insecurity about its contact with the United States. Even ten years after, the root of the problem was, of course, 1956.

The genesis myth of the Kádár regime hinged on both suppressing the actual memory and claiming the legacy of "the unfortunate events of October." In various white papers and fake "histories" (see for example Hollós 1967), Kádár and his team blamed the United States for the violence in late 1956. In this parallel reality, "mistakes of the past" separated the Rákosi era from the "new start" and "peaceful progress" of the post-1956 world. In May, Alexander cleverly lectured Kitty Havas on this contradiction (see footnote 3). Ten years after the Revolution, the newly-forged "Kádár compromise" depended on the (economic) goodwill of Washington, but the Hungarian party boss could neither make concessions to nor ask favors from the United States he himself blamed for the unnecessary bloodshed in 1956. The presence of Cardinal Mindszenty at the Legation added insult to injury and made life more difficult for both sides. Communist insecurity was further fuelled by the glaring gap between official hate speech targeting the United States and the immense popularity of American culture in Hungary, dating back to the interwar years. A divided Hungarian Socialist Workers' Party leadership could not decide which path to follow. Economists pushed for sacrificing prestige for loans, while the security establishment pursued a hard line even at the expense of occasionally sabotaging ongoing diplomatic talks. Cases in point include, on one side, the IMF talks between 1966 and 1968 and economic reforms in 1968 (Mong 2012), and, on the other side, the resumption of physical attacks on the US Embassy in 1967 and the expulsion of Columbia historian István Deák in 1973 on undisclosed charges (Borhi 2015: 223, 322-4). For the first five years of actual post-1956 diplomatic talks between the two countries (1964-69), Hungary negotiated not to achieve progress through compromise but to present the United States in a negative light. Magyarics concludes that the new "Hungarian party elite was held hostage by its own legitimizing myth of 1956 and felt that breaking out of it would mean the end of their political careers" (Magyarics 1994: 143, translation mine).

Throughout the Cold War, the United States handled Hungary from a position of power: the New World giant had nothing to gain from improving relations while the very survival of Kádár's regime depended on Western loans. The Kennedy administration helped stabilize the situation inside Hungary by extorting a series of amnesties from Kádár by 1963 but was not motivated to move forward or grant concessions to a totalitarian regime under foreign occupation. However, the policy of exporting American culture coincided with Washington's desire to promote diversity beyond the Iron Curtain, and preferences were adjusted accordingly. The February 1965 siege of the Budapest Legation was a grim reminder that the Hungarian

\footnotetext{
12 “Increased Tension in Cultural relations," Budapest Legation to State, June 23, 1966, 2 pages, NARA, RG 59 General Records of the Department of State, Central Foreign Policy Files, 1964-66, Box 340, Folder: CUL CCULTURE HUNG - A 1/1/64.
} 
concessions made in 1964 were not meant to last. Sending Edward Alexander, a professional Cold Warrior of VOA background, to Budapest was a risky move that paid off. He successfully eased official Hungarian fears of the United States taking advantage of the tenth anniversary of the Revolution. But, in his other capacity, Alexander also sabotaged Hungarian cultural policy by fraternizing with blacklisted painters and openly promoting American culture through the unauthorized American Library and in Nagyvilág. American diplomats had been expelled from communist countries for much less than what he did in 1966 alone. The fact that this did not happen indicates a shift in Hungarian domestic politics that American diplomats clearly missed. György Aczél assumed control of Hungarian cultural policies in early 1967 and ushered in a compromise between leading intellectuals and the Kádár regime, which, in turn, strengthened the narrative of an "internally liberal" Hungary gradually becoming the "happiest barrack" behind the Iron Curtain.

The key message of the cultural diplomatic survey of bilateral relations in 1966 presented above is that the tenth anniversary was a turning point in public diplomacy and in domestic Hungarian cultural politics, but not in US foreign policy towards the region. As has been pointed out twice before, what did not happen mattered as much as what did. Washington chose not to push Budapest on 1956, and the physical attacks on the US Legation were suspended. Hungary turned a blind eye to Alexander's unusual actions in Budapest (perhaps because of his mediation as press secretary), and the United States used the unfortunate passing of her chief diplomat there to make a unilateral gesture by offering to raise diplomatic relations to the ambassadorial level. The uneventful tenth anniversary of the "counter-revolution" gave the necessary confidence to Kádár to go ahead with domestic liberalization, while the State Department missed these signals and decided not to adjust its course. Genuine normalization of bilateral relations began only with the incoming Nixon administration in the summer of 1969, but only after the two foreign services had weathered the storms of 1967 (renewed attacks on the Embassy and ambassadordesignate János Radványi's desertion) and 1968 (the resumption of the jamming of American radios and Hungarian participation in the joint Warsaw Pact invasion of Czechoslovakia).

\section{Works Cited}

$\underline{\text { Archival Sources }}$

Edward Alexander's reports from Hungary, 1965-66: National Archives and Records Administration, Archives II at College Park, MD, Record Group 59: Records of the Department of State, Central Foreign Policy Files, 1964-66, Box 340.

\section{Secondary Sources}

Alexander, Edward. 1990. The Serpent and the Bees: A KGB Chronicle. Lanham, MD: UP of America.

Andrási, Gábor. 1991. “A Zuglói Kör (1958-1968)” ['The Zugló Circle, 1958-1968']. Ars Hungarica 19/1: 47-64. 
Borhi, László. 2015. Nagyhatalmi érdekek hálójában. Az Egyesült Államok és Magyarország kapcsolata a második világháborútól a rendszerváltásig ['In the Web of Great Power Politics: United States-Hungarian Relations from World War II to 1989']. Budapest: Osiris-MTA BTK TTI. (This book has been published in English but was not available in Hungary at the time of writing this article: Dealing with Dictators: The United States, Hungary, and East Central Europe, 1942-1989. Bloomington: Indiana UP, 2016. Trans. Jason Vincz.)

Ceplair, Larry and Christopher Trumbo. 2010. Dalton Trumbo: Blacklisted Hollywood Radical. Lexington, KY. UP of Kentucky.

Glant, Tibor. 2007. Remember Hungary 1956: Essays on the Hungarian Revolution and War of Independence in American Memory. Wayne, NJ: Center for Hungarian Studies and Publications, Inc.

. 2008. "Amerikás könyvek és Amerika-kép a két világháború közti Magyarországon" ['Books on America and Images of the US in Interwar Hungary']. In 'Minden gondolatomra számtalan másik árnya hull...' Emlékkönyv Frank Tibor 60. születésnapjára ['Festschrift for Tibor Frank's Sixtieth Birthday']. Eds. Tamás Magyarics and Miklós Lojkó. Budapest: Prima Rate Kft.: 79-85. . 2010. "Travel Writing as a Substitute for American Studies in Hungary." Hungarian Journal of English and American Studies. 16/1-2: 171-84.

—. 2013. Amerika, a csodák és csalódások földje. Az Amerikai Egyesült Államok képe a hosszú XIX. századi magyar utazási irodalomban ['America, Land of Miracles and Disappointments: The Image of the United States in Hungarian Travel Writing during the Long Nineteenth Century']. Debrecen: Debrecen UP.

Hollós, Ervin. 1967. Kik voltak, mit akartak? ['Who Were They and What Did They Want?']. Budapest: Kossuth.

Kovrig, Bennett. 1991. Of Walls and Bridges: The United States and Eastern Europe. New York: New York UP.

Luard, Evan. 1989. A History of the United Nations. Volume 2: The Age of Decolonization, 1955-1965. New York: St. Martin's Press.

McCauley, Brian. 1981. "Hungary and Suez, 1956: The Limits of Soviet and American Power." Journal of Contemporary History 16/4: 777-800.

Magyarics, Tamás. 1994. Az amerikai-magyar kapcsolatok, 1957-1967 ['US-Hungarian Relations, 1957-1967’]. Kandidátusi értekezés. Budapest. This was his postdoctoral dissertation. An abbreviated version was published as “Az Egyesült Államok és Magyarország: 1957-1967” [The United States and Hungary, 1957-67']. Századok. 130/3 (1996): 571-612.

Medalis, Christopher. 2009. American Cultural Diplomacy, the Fulbright Program, and US Hungarian Higher Education Relations in the Twentieth Century. Ph.D. diss. Columbia University.

Mong, Attila. 2012. Kádár hitele ['Kádár's Loans']. Budapest: Libri.

Szemjonov, J. N. 1953. A fasiszta geopolitika az amerikai imperializmus szolgálatában ['Fascist Geopolitics in the Service of American Imperialism']. Budapest: Szikra. 
Glant, Tibor. "US-Hungarian Relations Ten Years After 1956." Hungarian Cultural Studies. e-Journal of the American Hungarian Educators Association, Volume 9 (2016): http://ahea.pitt.edu DOI: 10.5195/ahea.2016.262

Tuch, Hans. 1988. "Interview with Edward Alexander, July 26, 1998." The Association for Diplomatic Studies and Training, Foreign Affairs Oral History Project, Information Series, 34 pages, typed transcript:

http://www.google.hu/url?sa=t\&rct=j\&q=\&esrc=s\&source=web\&cd=11\&ved=0ahUKE wifmvee Y7OAhUGiywKHQ4tDy8QFghJMAo\&url=http\%3A\%2F\%2Fwww.adst.org\% 2FOH\%2520TOCs\%2FAlexander\%2C\%2520Edward.toc.pdf\&usg=AFQjCNHqRoKN2 UNyhQgQKEN56TGPhoeh1g\&bvm=bv.127984354,d.bGg. 